\title{
Evaluation of pirenzepine on gastric acidity in healthy volunteers using ambulatory 24 hour intragastric $\mathrm{pH}$-monitoring
}

\author{
A ETIENNE, C J FIMMEL, B A BRON, E LOIZEAU, AND A L BLUM \\ From the Division of Gastroenterology and Nutrition, Department of Medicine, University of Geneva, \\ Geneva; and the Department of Medicine, Triemli Hospital, Zürich, Switzerland
}

SUMMARY The effect of pirenzepine on 24 hour intragastric acidity was studied in 10 healthy volunteers using ambulatory 24 hour intragastric $\mathrm{pH}$-monitoring in a double blind crossover study. Tests were performed on the seventh day of ingestion of either placebo, $75 \mathrm{mg}$ pirenzepine or $150 \mathrm{mg}$ pirenzepine per day. The drugs were given at two doses at 8.30 am and $8.30 \mathrm{pm}$. Mean nocturnal hydrogen ion activity during placebo treatment was $68 \mathrm{mmol} / 1 \pm 9$ SEM and was reduced by $75 \mathrm{mg}(26 \%, \mathrm{p}<0.01)$ and $150 \mathrm{mg}$ of pirenzepine $(36 \%, \mathrm{p}<0.01)$, respectively. Mean diurnal hydrogen ion activity was $32 \mathrm{mmol} / 1 \pm 6 \mathrm{SEM}$ and was not significantly reduced $(p>0 \cdot 1)$ by either dose of pirenzepine ( $4 \%$ and $12 \%$ respectively). Thus, the effect of pirenzepine on intragastric acidity is small, even with high doses of the drug, and becomes apparent only during the night.

Clinical studies have shown that pirenzepine, a selective antimuscarinic compound, ${ }^{12}$ is superior to placebo in the treatment of duodenal ulcer disease. ${ }^{3}$ The drug has been shown to reduce gastric volume secretion, ${ }^{45}$ but the effect of chronic ingestion on gastric acidity has not been evaluated in man. The aim of the present study was therefore to evaluate the effect of a high and a low oral dose of pirenzepine on 24 hour gastric acidity in healthy subjects. Gastric $\mathrm{pH}$ was monitored by means of continuous electrode measurements which has been validated in our laboratory. ${ }^{6}$ The day to day reproducibility of the method was tested in a series of repeat measurements during placebo treatment.

\section{Methods}

\section{SUBJECTS}

Ten healthy volunteers (six men, four women, median age 25 years) participated in the study. Informed consent was obtained in all cases, and the protocol was approved by the local ethical committee.

Gastric $\mathrm{pH}$ was measured by miniature glass electrodes (Radiometer Copenhagen GK282C)

Address for correspondence: Andre L Blum, MD, Gastrolabor. Triemlispital, $\mathrm{CH}-8063$ Zürich, Switzerland.

Received for publication 18 May 1984 connected to a $\mathrm{pH}$ meter with digital read-out (Metrohm E 602, $\mathrm{T}^{\circ}: 37^{\circ} \mathrm{C}$ ) and an analogical recorder (Tarcan $\mathrm{W}+\mathrm{W}$, chosen speed: $12 \mathrm{~cm} / \mathrm{h}$ ). Before and after each 24-hour test, the electrodes were calibrated with commercial buffer solutions (Ingold $\mathrm{pH} 7, \mathrm{pH} 4.01$ and $\mathrm{pH} 1.679$ ). The precision of the electrodes was excellent: the drift at the end of the recorded periods was negligible - that is, $<0 \cdot 1$ $\mathrm{pH}$ unit, $\mathrm{pH}$ values during final calibration being as follows (mean $\pm \mathrm{SD}, \mathrm{N}=37$ experiments): $6.98 \pm 0.07,4.03 \pm 0.06,1.66 \pm 0.08$ for the three buffer solutions, respectively.

The electrodes were positioned in the gastric corpus under fluoroscopical control. The measuring tip was situated $10 \mathrm{~cm}$ below the cardia. The $\mathrm{pH}$ values were continuously recorded on a writer which was mounted on a trolley. During the tests, the volunteers could move around the ward. Measurements began at 8.30 am after a 12 hour fast and lasted for 24 hours. Subjects had three standardised meals (breakfast at $9 \mathrm{am}$, lunch at 12 noon, and dinner at $6 \mathrm{pm}$ ). The total energy content was 8014 $\mathrm{kJ}$. Subjects were allowed to drink tap water ad libitum but had to record water intake.

The two doses of pirenzepine and placebo were administered according to a double blind cross over protocol. The three separate seven day treatment periods were at least one week apart. Pirenzepine 
was administered by mouth in daily doses of either two times $37.5 \mathrm{mg}$ or two times $75 \mathrm{mg}$, taken at 8.30 $\mathrm{am}$ and $8.30 \mathrm{pm}$. Seven of the 10 volunteers performed a second placebo test under identical conditions. The $\mathrm{pH}$ recording was performed on the seventh day of each treatment period. Blood samples for a pirenzepine radioimmunoassay were taken at $8 \mathrm{am}, 2 \mathrm{pm}$ and $8 \mathrm{pm}$ on the day of the $\mathrm{pH}$ metry. The assay detected pirenzepine at concentrations of 1 nanogram per millilitre. ${ }^{7}$

\section{EXPRESSION OF RESULTS}

Separate calculations were performed for the day period $(8.30 \mathrm{am}$ to $8.30 \mathrm{pm})$, the night period $(8.30$ $\mathrm{pm}$ to $8.30 \mathrm{am})$ and the whole 24 hour period. $\mathrm{pH}$ values were read every 10 minutes from the printout and converted to hydrogen ion activity. ${ }^{8}$ Statistical comparisons were made using two-way analysis of variance $^{9}$ of hydrogen ion activity. In threshold curves, the time period during which the intragastric $\mathrm{pH}$ was above a certain $\mathrm{pH}$ value was expressed in per cent of a 24 hour time period. ${ }^{10}$

\section{Results}

\section{REPRODUCIBILITY}

Mean 24-hour $\mathrm{H}+$ activity of seven volunteers was similar in two separate placebo tests (Table).

\section{STUDY COMPLIANCE}

All subjects tolerated the $\mathrm{pH}$ recording well. Two volunteers taking $150 \mathrm{mg}$ of pirenzepine complained of a dry mouth. No other side effects of pirenzepine were noticed.

\section{EFFECT OF PIRENZEPINE ON INTRAGASTRIC ACIDITY}

The mean hydrogen ion activity is shown in the Figure (upper graph). Individual values for day and night times are given in the Table. As compared with placebo, the mean 24 hour $\mathrm{H}+$ activity was reduced by $19 \%$ and $29 \%$ under the two regimens of 75 and $150 \mathrm{mg}$ of pirenzepine, respectively $(p<0.001)$. The reduction of intragastric $\mathrm{H}+$ activity during the day time was not significant (4\% and $12 \%$ respectively, $\mathrm{p}>0 \cdot 10$ ). During the night time, the reduction was statistically significant $(26 \%$ and $36 \%$ respectively, $\mathrm{p}<0.001)$. A dose of $150 \mathrm{mg}$ of pirenzepine per day was more effective than a dose of $75 \mathrm{mg}$, but the difference was only significant ' $(\mathrm{p}<0.05)$ at night. The $\mathrm{pH}$ threshold curves as shown in the figure are similar with placebo and with the two doses of pirenzepine for the whole 24 hour period (lower graph).

\section{SERUM PIRENZEPINE CONCENTRATIONS}

The plasma concentrations of pirenzepine correlated well with the ingested doses (mean \pm SEM, ten subjects): with placebo, they were always under the limit of detectability of the method; with pirenzepine $75 \mathrm{mg} / \mathrm{d}$, the plasma concentrations were $27 \pm 3 \cdot 7,34 \pm 5 \cdot 5$ and $26 \pm 2 \cdot 7 \mathrm{ng} / \mathrm{ml}$ at $8 \mathrm{am}, 2$ $\mathrm{pm}$ and $8 \mathrm{pm}$ respectively; with pirenzepine 150 $\mathrm{mg} / \mathrm{d}$, the corresponding values were $53 \pm 4 \cdot 3$,

Table Individual mean hydrogen ion activities ( $\mathrm{mmol} / \mathrm{l})$ for day time $(8.30 \mathrm{am}-8.30 \mathrm{pm}$ ) and night time $(8.30 \mathrm{pm}-8.30 \mathrm{am})$

\begin{tabular}{|c|c|c|c|c|c|c|c|c|}
\hline \multirow{3}{*}{$\begin{array}{l}\text { Subject } \\
\text { (no) }\end{array}$} & \multicolumn{4}{|c|}{ Placebo } & \multicolumn{4}{|c|}{ Pirenzepine } \\
\hline & \multicolumn{2}{|l|}{ Day } & \multicolumn{2}{|l|}{ Night } & \multicolumn{2}{|l|}{ Day } & \multicolumn{2}{|l|}{ Night } \\
\hline & Test 1 & Test 2 & Test 1 & Test 2 & $75 \mathrm{mg}$ & $150 \mathrm{mg}$ & $75 \mathrm{mg}$ & $150 \mathrm{mg}$ \\
\hline 1 & 28 & 31 & 78 & 59 & 35 & 31 & 76 & 63 \\
\hline 2 & 42 & 31 & 115 & 121 & 48 & 23 & 103 & 75 \\
\hline 3 & 61 & 65 & 57 & 56 & 25 & 32 & 26 & 36 \\
\hline 4 & 15 & 25 & 43 & 34 & 13 & 19 & 21 & 25 \\
\hline 5 & 61 & 52 & 67 & 65 & 48 & 58 & 43 & 46 \\
\hline 6 & 23 & 31 & 68 & 62 & 20 & 25 & 54 & 46 \\
\hline 7 & 35 & 43 & 46 & 35 & 34 & 31 & 30 & 22 \\
\hline 8 & 23 & - & 74 & - & 46 & 24 & 65 & 49 \\
\hline 9 & 18 & - & 105 & - & 16 & 9 & 58 & 57 \\
\hline 10 & 17 & - & 28 & - & 24 & 24 & 27 & 13 \\
\hline Mean $(1-10)$ & 32 & - & 68 & - & 31 & 28 & 50 & 43 \\
\hline SEM $(1-10)$ & 6 & - & 9 & - & 4 & 4 & 8 & 6 \\
\hline Mean (1-7) & 38 & 40 & 68 & 62 & & & & \\
\hline $\operatorname{SEM}(1-7)$ & 7 & 5 & 9 & 11 & & & & \\
\hline
\end{tabular}



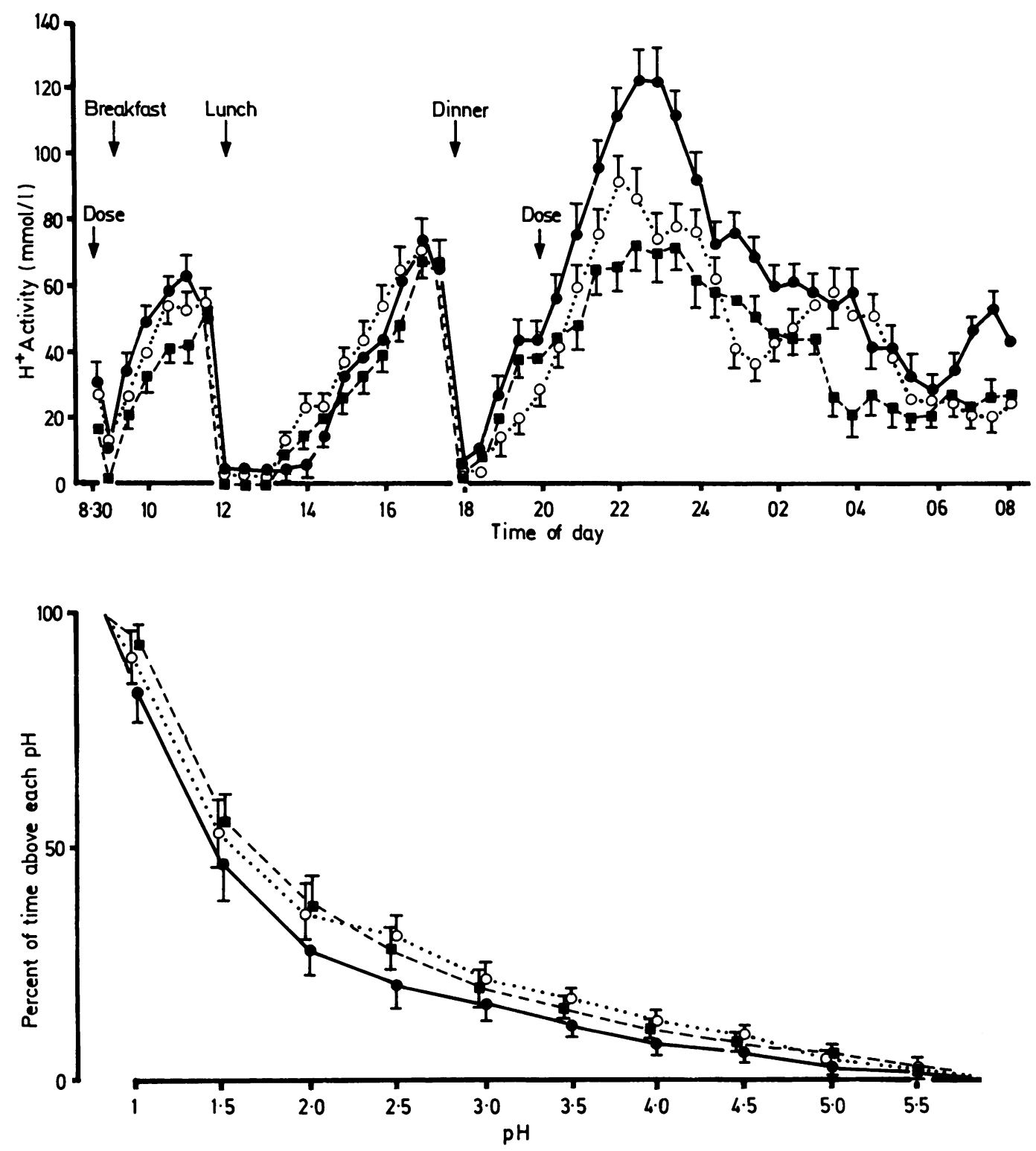

Figure Upper graph: Twenty four hour hydrogen ion activity (mmolll) during treatment with pirenzepine $75 \mathrm{mg} / \mathrm{d}$, pirenzepine $150 \mathrm{mg} / \mathrm{d}$ or placebo. Each point is the mean $\mathrm{H}+$ activity of 10 healthy subjects. Each bar is the standard error of the mean (SEM). For the sake of clarity, we display only one value every 30 minutes, and the SEM when feasible. Lower graph: $p H$ threshold curves. Mean \pm SEM of ten volunteers. Each point shows the time (expressed in percent of a 24 hour period) during which $p H$ was above a given threshold. For example, $p H$ was above 2 during $27.5 \%$ of the 24 hour period (corresponding to 6 hours and 36 minutes) when the subjects were treated with placebo. Placebo: ——. Pirenzepine $37.5 \mathrm{mg}$ twice daily: ——_ Pirenzepine $75 \mathrm{mg}$ twice daily: 
$72 \pm 9 \cdot 0$ and $50 \pm 4 \cdot 6 \mathrm{ng} / \mathrm{ml}$ respectively. No correlation was found between the effect of pirenzepine on acidity and the serum concentrations.

\section{Discussion}

In the present study we have evaluated the effect of long term administration of pirenzepine on gastric acidity using a new method of continuous intragastric $\mathrm{pH}$-metry. We have recently validated this method ${ }^{6}$ and its good reproducibility was again shown in repeat placebo tests in seven volunteers (Table).

Hydrogen ion activity during placebo treatment was, on average, $30-40 \mathrm{mmol} / \mathrm{l}$ during the day and much higher - that is, $60-70 \mathrm{mmol} / \mathrm{l}$, at night. Similar findings were reported by others. ${ }^{11}$ Pirenzepine had only a small effect on intragastric $\mathrm{pH}$. Even a high dose of $150 \mathrm{mg}$ which may cause anticholinergic side effects, reduced nocturnal acidity by only $36 \%$ and had no measurable effect on diurnal acidity. It is surprising that such a small reduction of acid concentration may be sufficient for the acceleration of ulcer healing. It might be argued that the effect of pirenzepine decreases over time and might be higher on the first than on the seventh day of treatment. Pirenzepine is, however, given to ulcer patients at a fixed dose during several weeks. Thus, the effect seen in the present study is more representative of what happens in a clinical setting than in studies where the drug is given only on one day. It might further be argued that pirenzepine may reduce gastric volume output even in the absence of an effect on hydrogen ion activity ${ }^{45}$ and that this volume effect may, on its own, reduce duodenal bulb acidity. Pirenzepine has, however, also been shown to accelerate gastric ulcer healing. ${ }^{12}$ Therefore, it is uncertain whether there is a direct relationship between the extent of secretory inhibition and therapeutical efficacy of a drug. Future studies with drugs which almost completely inhibit acid production ${ }^{13} 14$ will shed more light on this point. In all other circumstances slightly 'tipping the balance' might be as effective as a strong inhibitory effect. ${ }^{95-17}$ Low dose antacid regimen, which has an effect on acidity comparable to that of pirenzepine,$^{18}$ has been recently shown to have an effect similar to that of cimetidine in duodenal ulcer treatment. ${ }^{19}$ Therefore, long term secretory tests are useful for the characterisation of antisecretory drugs, but it is difficult to predict from the results to what extent the drug accelerates ulcer healing.

\section{References}

1 Birsdall NJM, Burgen ASV, Hammer R, Hulme EC, Stockton J. Pirenzepine - a new ligand with original binding properties to muscarinic receptors. Scand $J$ Gastroenterol 1980; 15: suppl 66: 1-4.

2 Hammer R, Berrie CP, Birsdall NJM, Burgen ASV, Hulme EC. Pirenzepine distinguishes between different subclasses of muscarinic receptors. Nature 1980; 283: 90-2.

3 Bianchi-Porro G, Petrillo M. Pirenzepine in the treatment of peptic ulcer disease. Review and commentary. Scand J Gastroenterol 1981; 16: suppl 72: 229-35.

4 Bron BA, Infante F. Verhalten der basalen und der stimulierten Magensekretion während 6 Stunden nach parenteraler Gabe von Pirenzepine und Cimetidin. In: Blum AL, Hammer R, eds. Die Behandlung des Ulcus pepticum mit Pirenzepine. Gräfelfing: Demeter Verlag. 1979: 113-5.

5 Jaup BH, Stockbrügger RW, Dotevall G. Comparison of the action of pirenzepine and L-hyoscyamine on gastric acid secretion and other muscarinic effects. Scand J Gastroenterol 1980; 15: suppl 66: 89-94.

6 Fimmel CJ, Etienne A, Gasser T et al. Longterm ambulatory gastric $\mathrm{pH}$ monitoring - validation of a new method and effect of $\mathrm{H}_{2}$-antagonists. Gastroenterology 1985. (In press).

7 Bozler G. The specific radioimmunoassay in pharmacokinetics. In: Proceedings of the international symposium on radioimmunoassay and related procedures in medicine. Vienna: International Atom Energy, 1978: 299-308.

8 Moore EW, Scarlata RW. The determination of gastric acidity by the glass electrode. Gastroenterology 1965 ; 49: $178-88$.

9 Lellouch J, Lazar P. Méthodes statistiques en expérimentation biologique. In: Flammarion Médecine Sciences, ed. Statistique en biologie et médecine. Paris: Flammarion, 1974: 43-52.

10 Peterson WL, Barnett C, Feldmann M, Richardson CT. Reduction of twenty-four-hour gastric acidity with combination drug therapy in patients with duodenal ulcer. Gastroenterology 1979; 77: 1015-20.

11 Milton-Thompson GJ. Monitoring of 24-h acid secretion during antacid treatment. In: Halter $F$, ed. Antacids in the eighties. Muenchen-Wien-Baltimore: Urban \& Schwarzenberg, 1982: 54-7.

12 Morelli A, Pelli A, Narducci F, Spadacini A. Pirenzepine in the treatment of gastric ulcer. Scand $J$ Gastroenterol 1979; 14: suppl 57: 51-5.

13 Walt RP, Gomez de MFA, Wood EC, Logan LH, Pounder RE. Effect of daily oral omeprazole on 24 hour intragastric acidity. $\mathrm{Br}$ Med J 1983; 287: 12-4.

14 Gustavsson S, Lööf L, Adami HO, Nyberg A, Nyrén O. Rapid healing of duodenal ulcers with omeprazole. Lancet 1983; 2: 124-5.

15 Brunner H, Dittrich H, Kratochvil P et al. Treatment of duodenal ulcer with pirenzepine and cimetidine. Gut 1984; 25: 206-11.

16 Isenberg JI, Peterson WL, Elashoff JD et al. Healing of benign gastric ulcer with low-dose antacid or 
cimetidine. N Engl J Med 1983; 308: 1319-24.

17 Pace F and the GELUMET Cooperative Study Group. Determinants of gastric ulcer healing. [Abstract] Gastroenterology 1983; 84: 1268.

18 Etienne A, Fimmel CJ, Rey JP, Blum AL. Longlasting effect of an $\mathrm{Al} / \mathrm{Mg}$ liquid antacid on nocturnal intragastric acidity recorded by continuous $\mathrm{pH}$-metry. [Abstract] Gastroenterology 1984; 86: 1071.

19 Lux G, Hentschel H, Rohner G, Brunner H, Rösch W. Niedrig dosiertes Antazidum (280 mval/Tag) in der Therapie des Ulcus duodeni. [Abstract] $Z$ Gastroenterol 1983: 21: 438. 